\title{
Expression of Crossreactive Idiotypes by Human Antibodies Specific for the Capsular Polysaccharide of Hemophilus influenzae B
}

\author{
Alexander H. Lucas \\ Pediatric Immunology and Allergy Division, Department of Pediatrics, University of California, San Diego, La Jolla, California 92093
}

\begin{abstract}
Human antibodies specific for polyribosyl-ribitol-phosphate (PRP), the capsular polysaccharide of Hemophilus influenzae b, were studied using idiotypic analysis. Antisera were prepared against purified $F\left(a^{\prime}\right)_{2}$ anti-PRP from two unrelated adults, H.H. and P.T. After repeated absorption with IgG myeloma proteins and with PRP-absorbed normal human Ig and donor Ig, anti-idiotypic (anti-Id) sera were obtained that specifically reacted with anti-PRP antibodies. Anti-Id ${ }^{\mathrm{HH}}$ and anti-Id ${ }^{\mathrm{PT}}$ reciprocally crossreacted with $\mathrm{H} . \mathrm{H}$. and P.T. antiPRP antibodies and $F\left(a^{\prime}\right)_{2}$ fragments, and also reacted with the serum anti-PRP antibodies from three additional adults unrelated to P.T. and H.H. Both anti-Id sera partially inhibited anti-PRP paratopes but not anti-tetanus toxoid paratopes. PRP did not inhibit anti-Id recognition of shared or crossreactive idiotypic (CRI) determinants. Naturally occurring and PRP immunization-induced anti-PRP antibodies expressed CRI. While CRI titer increased after immunization, the increase was usually less than the rise in total anti-PRP antibody. Quantitative differences in CRI expression were also apparent between natural and immunization-induced H.H. and P.T. anti-PRP antibodies as shown by their differential inhibitability by anti-Id. Our data demonstrate that anti-PRP antibodies from five unrelated adults express CRI determinants that are probably distant from the PRP combining site. Naturally occurring and immunization-induced anti-PRP antibodies share CRI and therefore appear to be clonally related, although immunization apparently induces the expression CRInegative antibodies as well. These results, taken with previous studies showing restricted and identical anti-PRP isoelectric focusing spectrotypes in unrelated adults, suggest that some PRP-specific V domains are structurally conserved and probably germ-line encoded.
\end{abstract}

\section{Introduction}

The encapsulated bacterium, Hemophilus influenzae b (Hib), ${ }^{1}$ is the primary cause of meningitis in the United States and is

Dr. Lucas's current address is Dept. of Immunology, IMM1, Research Institute of Scripps Clinic, 10666 North Torrey Pines Road, La Jolla, CA 92037.

Received for publication 14 May 1987 and in revised form 21 September 1987.

1. Abbreviations used in this paper: anti-Id, anti-idiotype; CRI, crossreactive idiotype; Hib, Hemophilus influenzae type b; Id, idiotype; $\mathrm{Id}^{\mathrm{HH}}$ and $\mathrm{Id}^{\mathrm{PT}}$, purified anti-PRP from individuals H.H. and P.T., respectively; IEF, isoelectric focusing; OD, optical density; PLA, phospholipase $\mathrm{A}_{2}$; PRP, polyribosyl-ribitol-phosphate.

J. Clin. Invest.

(c) The American Society for Clinical Investigation, Inc.

0021-9738/88/02/0480/07 \$2.00

Volume 81, February 1988, 480-486 the etiologic agent in other serious invasive diseases (1). Serum antibodies specific for the Hib capsular polysaccharide, polyribosyl-ribitol-phosphate (PRP), confer resistance to Hib infection and, like antibodies to many other bacterial polysaccharides, their expression is age related. Children $<2$ yr of age generally synthesize little anti-PRP antibody either spontaneously or in response to parenteral immunization with PRP, whereas older children and adults have protective levels of so-called natural antibody and upon immunization they respond with increased levels of specific antibody (2-6).

Elucidating the mechanisms involved in the ontogeny and regulation of the PRP-specific antibody response requires information as to the repertoire size. Recent progress was made in this area by Insel et al., who used isoelectric focusing (IEF) analysis to show that human antibodies to PRP were of limited structural diversity $(7,8)$. Anti-PRP IEF patterns consisted of only a few predominant spectrotypes, and in some cases they appeared as restricted as monoclonal antibody. Moreover, the spectrotypes of unrelated individuals were remarkably similar. These findings indicate that the anti-PRP antibody response is pauciclonal and is composed of structurally conserved molecules.

Another approach to assess the diversity of the anti-PRP antibody repertoire is by characterization of idiotypes (Ids). Idiotypic analysis could provide insight into the question of whether the limited polymorphism observed with IEF is due to variable region restriction. Such knowledge might help clarify the mechanisms generating anti-PRP antibody diversity in humans, and also could provide an experimental system in humans for addressing the issue of Id regulation and the possible role it may play in the ontogeny of anti-carbohydrate immunity. Studies in several experimental systems have demonstrated that anti-Id antibodies can induce specific immunity to infectious agents (9-14). This strategy, which may be feasible for inducing human immunity to Hib, requires knowledge of anti-PRP-associated Ids.

Given these considerations, we undertook an Id analysis of adult anti-PRP antibodies. The data presented here demonstrate Id crossreactivity between the anti-PRP antibodies of five unrelated adults. The expression of recurrent, crossreactive Ids (CRIs) in unrelated individuals, taken with the aforementioned IEF analyses, indicate that some PRP-specific V regions are structurally conserved and are probably encoded by homologous germ-line $\mathrm{V}$ region genes.

\section{Methods}

Human subjects and immunizations. Five normal, healthy, male and female adult volunteers were immunized with $40 \mu \mathrm{g}$ PRP vaccine (provided by Dr. Porter Anderson, University of Rochester, Rochester, NY) subcutaneously over the deltoid area. Blood was drawn before immunization and 2-3 wk after immunization. Informed consent was obtained from all subjects. Immunizations and blood drawings followed an institutionally approved protocol.

Mice. (BALB/c $\left.\times \mathrm{C}^{2} 7 \mathrm{BL} / 6\right) \mathrm{F}_{1}$ mice between 2 and 4 mo of age 
were obtained from the colony of Dr. Richard Dutton of this institution.

Preparation of immunoabsorbents. Purified PRP (obtained from Dr. Porter Anderson) was coupled to amino-hexyl-Sepharose 4B (Pharmacia Fine Chemicals, Piscataway, NJ). $10 \mathrm{mg}$ of PRP was dissolved in $5.0 \mathrm{ml} 0.2 \mathrm{M} \mathrm{NaHCO}_{3}$ and the $\mathrm{pH}$ adjusted to 10 . While stirring at $0^{\circ} \mathrm{C}, 500 \mathrm{mg}$ of $\mathrm{CNBr}$, dissolved in dimethyl formamide, were slowly added and the $\mathrm{pH}$ maintained at $9.2-9.5$ by addition of $\mathrm{NaOH}$. After $10 \mathrm{~min}, 4.5 \mathrm{ml}$ of $0.2 \mathrm{M} \mathrm{NaHCO}_{3}$ was added. The activated PRP was added to $10 \mathrm{ml}$ of swollen amino-hexyl-Sepharose $4 \mathrm{~B}$ and the mixture was rotated overnight at room temperature. The Sepharose was then reacted with $1 \mathrm{M}$ ethanolamine, $\mathrm{pH} 8.2$, for $1 \mathrm{~h}$, then alternately washed with $0.1 \mathrm{M} \mathrm{NaHCO}_{3}-0.25 \mathrm{M} \mathrm{NaCl}$ and $0.1 \mathrm{M}$ acetic acid- $0.25 \mathrm{M} \mathrm{NaCl}$. Analysis of the coupling supernatant for pentose, using the Dische modification of the Orcinol reaction (15), indicated that $100 \%$ of the PRP had been coupled, which resulted in a ratio of $1 \mathrm{mg}$ PRP per $\mathrm{ml}$ of swollen gel. The slurry was stored at $4^{\circ} \mathrm{C}$ in PBS with $0.1 \%$ sodium azide.

Purified human myeloma proteins (provided by Dr. Hans Spiegelberg, Scripps Clinic and Research Foundation, La Jolla, CA), human Ig preparations (see below), and phospholipase $A_{2}$ (PLA) from honey bee venom (Sigma Chemical Co., St. Louis, MO) were coupled to Sepharose 4B (Pharmacia Fine Chemicals) with CNBr according to the manufacturer's instructions, at a ratio of $10 \mathrm{mg}$ protein per $\mathrm{ml}$ swollen gel.

Preparation of human $1 \mathrm{~g}$ and isolation of PRP-specific antibodies. Individual postvaccination serum samples from individuals H.H. and P.T. and a serum pool from 10 normal donors were heat inactivated at $56^{\circ} \mathrm{C}$ for $30 \mathrm{~min}$. The Ig fraction was isolated by two precipitations with $50 \%$ saturated ammonium sulfate. After dialysis against PBS, the protein concentration was estimated using $\sum_{280}^{1 \%}=15$. To purify PRPspecific antibodies, P.T. or H.H. Ig was first absorbed with unmodified Sepharose to remove any antibodies reactive with the matrix. The Ig was then slowly passed through a small column of PRP-Sepharose. After washing the column with $0.5 \mathrm{M} \mathrm{NaCl}$ until no absorbance at 280 $\mathrm{nm}$ was detectable in the effluent, the bound protein was eluted with 3.5 M NaSCN, dialyzed extensively against PBS at $4^{\circ} \mathrm{C}$, and concentrated using pressure filtration. Protein concentration was calculated according to $\sum_{280}^{1 \%}=15$. Greater than $99 \%$ of the anti-PRP antibody activity was removed from Ig preparations by this procedure. This PRP-absorbed fraction was coupled to Sepharose 4B. Analysis of purified antibodies on reducing SDS-acrylamide gels stained with silver showed predominantly $\mathrm{H}$ and $\mathrm{L}$ chains with traces of high molecular weight contaminants. $F\left(a^{\prime}\right)_{2}$ fragments of the affinity purified antiPRP antibodies were made by pepsin digestion overnight in acetate buffer, pH 4.9 (16).

Antibodies specific for PLA of honey bee venom were isolated from the Ig fraction of serum from a professional bee keeper, by absorption to PLA-Sepharose and elution with $3.5 \mathrm{M} \mathrm{NaSCN}$.

Preparation of anti-idiotypic (anti-Id) antisera. $\mathrm{F}\left(\mathrm{ab}^{\prime}\right)_{2}$ anti-PRP from donors H.H. and P.T., emulsified in complete Freund's adjuvant, was injected into $(\mathrm{BALB} / \mathrm{c} \times \mathrm{C} 57 \mathrm{BL} / 6) \mathrm{F}_{1}$ mice in several subcutaneous sites and in the rear foot pads ( $100 \mu \mathrm{g}$ total/mouse). 3 wk later the mice were boosted with $\mathrm{F}(\mathrm{ab})_{2}$ in incomplete adjuvant with the same dose and route. Mice were given a third injection of $50 \mu \mathrm{g} \mathrm{F}\left(\mathrm{ab}^{\prime}\right)_{2}$, in alum, intraperitoneally. Mice were bled 7-10 d after the second and third injections. The sera were pooled and sequentially absorbed with three different absorbents: Sepharose coupled with either human IgG myeloma proteins, pooled normal human Ig depleted of PRP-specific antibodies, or Ig from the anti-PRP donor depleted of PRP-specific antibodies. The resulting antisera were designated anti-Id ${ }^{\mathrm{HH}}$ and anti-Id ${ }^{\mathrm{PT}}$.

Idiotype assays. A direct binding ELISA assay was used to initially assess the anti-Id reagents. Wells of microtiter plates (U-bottom, polyvinyl chloride) were coated with purified anti-PRP antibodies $(2 \mu \mathrm{g} / \mathrm{ml}$ PBS, overnight at room temperature), or with PRP-absorbed Ig (10 $\mu \mathrm{g} / \mathrm{ml}$ PBS). The wells were blocked with PBS-1\% BSA (PBS-BSA) for 15 min, then washed with PBS-0.1\% Tween 20. Dilutions of anti-Id were added to the wells and the plates incubated for $3 \mathrm{~h}$ at $37^{\circ} \mathrm{C}$. The wells were washed three times with PBS-Tween, followed by addition of polyvalent goat anti-mouse Ig antibodies coupled with alkaline phosphatase (Tago, Inc., Burlingame, CA). The goat antibodies had no reactivity with human Ig. After $3 \mathrm{~h}$ at $37^{\circ} \mathrm{C}$, the wells were washed as before, then $50 \mu \mathrm{l}$ of $p$-nitrophenylphosphate, $1 \mathrm{mg} / \mathrm{ml}$ in $0.1 \mathrm{M}$ glycine- $0.001 \mathrm{M} \mathrm{MgCl}_{2}-0.001 \mathrm{M} \mathrm{ZnCl}_{2}, \mathrm{pH} 9.5$, was added. After 30 to 45 min at room temperature, the optical density (OD) at $405 \mathrm{~nm}$ was determined using a microelisa analyzer (Dynatech Laboratories, Alexandria, VA). Background OD values generated on wells coated with BSA and which received all other reagents were subtracted from respective test values.

An inhibition ELISA was used to assess specificity of anti-Id and to quantitate Id. A dilution of anti-Id giving an OD of $\sim 0.4$ in the direct binding assay (1:400 for anti-Id ${ }^{\mathrm{HH}}$ and 1:1,600 for anti-Id ${ }^{\mathrm{PT}}$ ) was incubated with varying concentrations of inhibitors for $2 \mathrm{~h}$ at $37^{\circ} \mathrm{C}$, after which the mixtures were added to microtiter wells previously coated with $\mathrm{HH}$ anti-PRP $\left(\mathrm{Id}^{\mathrm{HH}}\right)$ or PT anti-PRP $\left(\mathrm{Id}^{\mathrm{PT}}\right)$ and blocked with PBS-BSA. The plates were incubated for $3 \mathrm{~h}$ at $37^{\circ} \mathrm{C}$, washed, then incubated with goat anti-mouse Ig antibodies coupled with alkaline phosphatase. After $3 \mathrm{~h}$ at $37^{\circ} \mathrm{C}$, the wells were washed and developed as described above. Color development proceeded until an OD of $\sim 0.5$ was obtained in the absence of inhibitor. All samples were tested in duplicate. Results are expressed as percent inhibition of anti-Id binding and were calculated according to: $\%$ inhibition $=100 \times 1$ - (OD with inhibitor)/(OD no inhibitor).

ELISA assay for PRP-specific and tetanus toxoid (TT)-specific antibodies. Dilutions of sera, Ig preparations, or purified antibodies were added to microtiter wells that had been coated with PRP-tyramine (17) $\left(3 \mu \mathrm{g} / \mathrm{ml} \mathrm{PBS}, 3 \mathrm{~h}\right.$ at $\left.37^{\circ} \mathrm{C}\right)$ and blocked with PBS-BSA. After $3 \mathrm{~h}$ at $37^{\circ} \mathrm{C}$ or overnight at $4^{\circ} \mathrm{C}$, the wells were washed, then polyvalent goat anti-human Ig antibodies coupled with alkaline phosphatase (Tago, Inc.) were added for $3 \mathrm{~h}$ at $37^{\circ} \mathrm{C}$. The wells were washed and developed as described above. All samples were tested in duplicate. The concentration of anti-PRP antibody was determined by comparison to a standard curve generated by a reference human anti-PRP serum containing $70 \mu \mathrm{g}$ anti-PRP antibody/ml (provided by Dr. John Robbins, National Institutes of Health, Bethesda, MD). Background $\mathrm{OD}$, generated by test samples incubated on BSA-coated wells, was subtracted from OD generated on PRP-coated wells. This assay has a sensitivity of $0.02 \mu \mathrm{g}$ anti-PRP antibody $/ \mathrm{ml}$. The assay is specific for anti-PRP antibodies, since all binding is inhibited by preincubation of sera with PRP but not with unrelated polysaccharides, and since absorption with PRP-Sepharose specifically removes binding activity.

Human antibodies specific for TT were measured as described in reference 18 .

\section{Results}

Binding of anti-Id to purified anti-PRP antibodies. Murine antisera were prepared against purified $F\left(a b^{\prime}\right)_{2}$ anti-PRP from two unrelated adults, H.H. and P.T. After absorption of the antisera with Sepharose coupled with human IgG myeloma protein, PRP-absorbed normal human Ig, and with PRP-absorbed donor Ig, anti-Id ${ }^{\mathrm{HH}}$ and anti-id ${ }^{\mathrm{PT}}$ were tested for their ability to bind to microtiter wells coated with anti-PRP antibodies (Id) or with PRP-absorbed Ig. Fig. 1 shows that anti$\mathrm{Id}^{\mathrm{HH}}$ reacted with $\mathrm{Id}^{\mathrm{HH}}$ and to a lesser extent with $\mathrm{Id}^{\mathrm{PT}}$. Anti$\mathrm{Id}^{\mathrm{PT}}$ reacted with $\mathrm{Id}^{\mathrm{PT}}$ and nearly as well with $\mathrm{Id}^{\mathrm{HH}}$. Neither anti-Id reacted with homologous or heterologous PRP-absorbed Ig.

Specificity of anti-Ids for anti-PRP antibodies. Various Ig preparations were tested in the ELISA inhibition assay for their ability to inhibit the binding of anti-Id to wells coated with homologous or heterologous Id. Fig. $2 \mathrm{~A}$ shows that the 

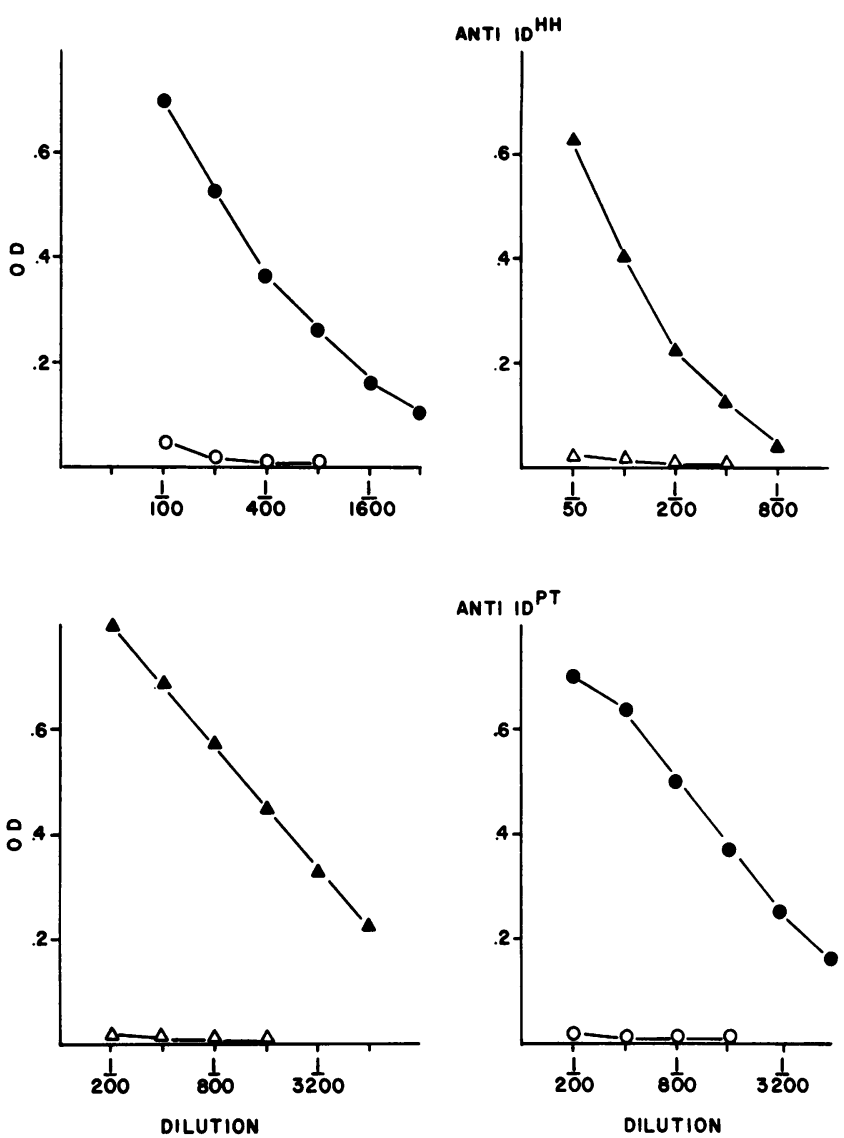

Figure 1. Binding of anti-Id ${ }^{\mathrm{HH}}$ and anti-Id ${ }^{\mathrm{PT}}$ to microtiter wells coated with $\mathrm{Id}^{\mathrm{HH}}(\bullet), \mathrm{Id}^{\mathrm{PT}}(\triangleleft)$, PRP-absorbed H.H. Ig (O), or PRP-absorbed P.T. Ig $(\Delta)$.

binding of anti-Id ${ }^{\mathrm{HH}}$ to $\mathrm{Id}^{\mathrm{HH}}$ was inhibited by $\mathrm{Id}^{\mathrm{HH}}$ and $\mathrm{F}\left(\mathrm{ab}^{\prime}\right)_{2}$ $\mathrm{Id}^{\mathrm{HH}}$, but was not inhibited by high concentrations of human myeloma proteins, PRP-absorbed polyclonal human Ig, PRPabsorbed H.H. or P.T. Ig, or affinity-purified human antibodies to PLA. Idiotypic crossreactivity was demonstrated by the ability of Id ${ }^{\mathrm{PT}}$ and $\mathrm{F}\left(\mathrm{ab}^{\prime}\right)_{2} \mathrm{Id}^{\mathrm{PT}}$ to inhibit the anti-Id ${ }^{\mathrm{HH}} \rightarrow \mathrm{Id}^{\mathrm{HH}}$ reaction. Approximately 10 times more $\mathrm{Id}^{\mathrm{PT}}$ was required to achieve the same level of inhibition as that obtained with $\mathrm{Id}^{\mathrm{HH}}$ To test for Ids shared between $\mathrm{Id}^{\mathrm{HH}}$ and $\mathrm{Id}^{\mathrm{PT}}$ and to eliminate reaction of anti-Id ${ }^{\mathrm{HH}}$ with Ids private to $\mathrm{HH}$, the reaction of anti-Id ${ }^{\mathrm{HH}}$ with $\mathrm{Id}^{\mathrm{PT}}$ was analyzed. As shown in Fig. $2 \mathrm{~B}, \mathrm{Id}^{\mathrm{HH}}$ and $\mathrm{Id}^{\mathrm{PT}}$ inhibited the heterologous reaction equally. No significant inhibition was observed with H.H. or P.T. PRP-absorbed Ig, anti-PLA antibodies, PRP-absorbed polyclonal Ig, or with myeloma proteins.

The same Ig preparations were tested for their ability to inhibit the reaction of anti-Id ${ }^{\mathrm{PT}}$ with either $\mathrm{Id}^{\mathrm{PT}}$ or $\mathrm{Id}^{\mathrm{HH}}$. As shown in Fig. 3, both the homologous and the heterologous reactions were inhibited by $I^{\mathrm{PT}}$ and $\left.\mathrm{Id}^{\mathrm{PT}} \mathrm{F}(\mathrm{ab})_{2}\right)_{2}$. PRP-absorbed PT Ig showed slight, $\sim 15 \%$, inhibition at $100 \mu \mathrm{g} / \mathrm{ml}$; however, $\sim 1,000$-fold less $\mathrm{Id}^{\mathrm{PT}}$ was required to achieve this same level of inhibition. No inhibition was observed with myeloma proteins, PRP-absorbed Ig, or anti-PLA antibodies. Idiotypic crossreactivity was shown by the ability of $\mathrm{Id}^{\mathrm{HH}}$ and $\mathrm{Id}^{\mathrm{HH}} \mathrm{F}\left(\mathrm{ab}^{\prime}\right)_{2}$ to effectively inhibit the homologous and heterologous reactions of anti-Id ${ }^{\mathrm{PT}}$. In contrast to the results with anti-Id ${ }^{\mathrm{HH}}$, the inhibitory activity of the heterologous Id, i.e.,
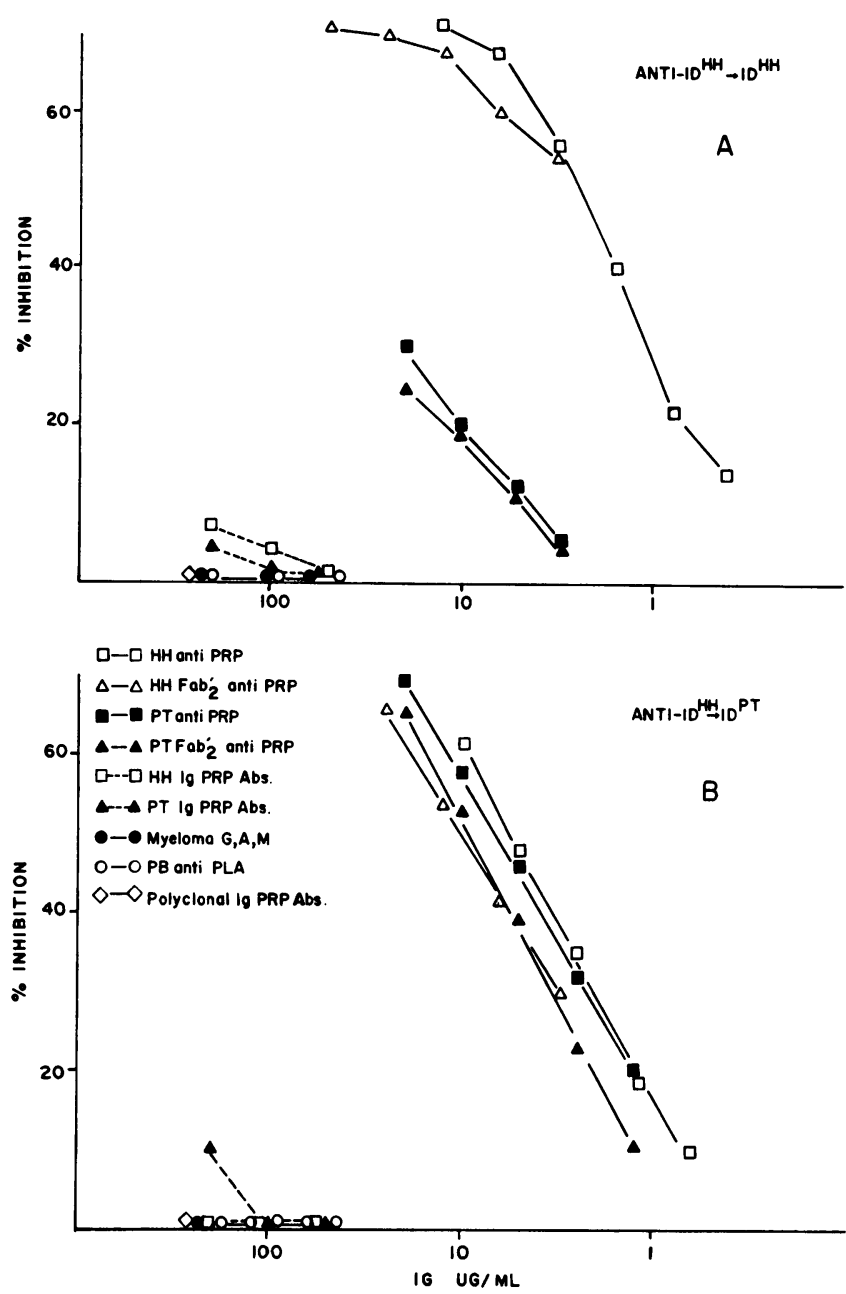

Figure 2. ELISA inhibition assay. Ability of various Ig preparations to inhibit the binding of anti-Id ${ }^{\mathrm{HH}}$ to $\mathrm{Id}^{\mathrm{HH}}(A)$ or $\operatorname{Id}^{\mathrm{PT}}(B)$. Abs, absorbed; G, A, M, IgG, IgA, IgM.

$\mathrm{Id}^{\mathrm{HH}}$, did not increase significantly when tested in the heterologous anti-Id $\rightarrow$ Id reaction.

Inhibition of the anti-Id $\rightarrow I d$ reaction with PRP. To assess whether anti-Id recognition of anti-PRP-associated Ids was affected by PRP, Id ${ }^{\mathrm{HH}}$ or $\mathrm{Id}^{\mathrm{PT}}$, which had been absorbed to microtiter wells, was first incubated with varying concentrations of PRP or as a control, with dextran B-1355, before addition of anti-Id ${ }^{\mathrm{HH}}$. Fig. $4 \mathrm{~A}$ shows that $40 \%$ inhibition of the binding of anti-Id ${ }^{\mathrm{HH}}$ to $\mathrm{Id}^{\mathrm{HH}}$ was achieved with $100 \mu \mathrm{g}$ PRP/ $\mathrm{ml}$. No inhibition was observed with dextran. The binding of anti-Id ${ }^{\mathrm{HH}}$ to $\mathrm{Id}^{\mathrm{PT}}$ was not inhibited by PRP (Fig. $4 \mathrm{~B}$ ). Anti$\mathrm{Id}^{\mathrm{PT}}$ was similarly tested, and neither the homologous nor the heterologous reaction was susceptible to PRP inhibition.

Inhibition of anti-PRP paratopes with anti-Id. Anti-Id ${ }^{\mathrm{HH}}$ and anti-Id ${ }^{\mathrm{PT}}$ were tested for their ability to inhibit the binding of anti-PRP to PRP. Specificity of the reaction was controlled by testing the effect of anti-Id on the binding of anti-TT antibodies to TT. The data in Table I demonstrate that pre- and post-PRP immunization antibody populations differed with respect to their inhibition by homologous anti-Id. Anti-Id ${ }^{\text {HH }}$ inhibited HH pre- and post-anti-PRP antibody activity by 73 and $51 \%$, respectively. Anti-Id ${ }^{\mathrm{PT}}$ inhibited PT pre- and postanti-PRP antibody by 0 and $34 \%$, respectively. Differences between the pre- and postvaccination antibody populations 

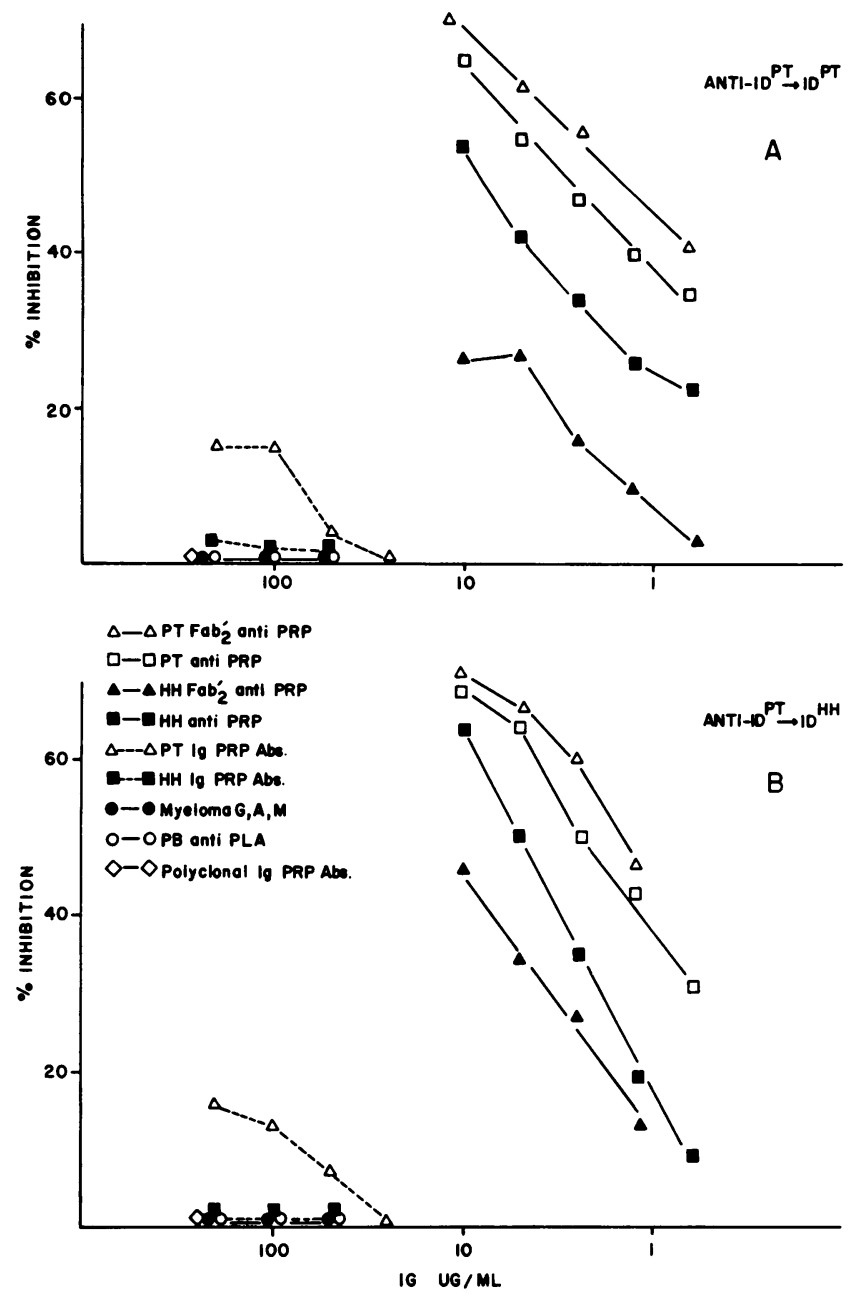

Figure 3. ELISA inhibition assay. Ability of various Ig preparations to inhibit the binding of anti-Id ${ }^{\mathrm{PT}}$ to $\mathrm{Id}^{\mathrm{PT}}(A)$ or $\mathrm{Id}^{\mathrm{HH}}(B)$. Abs, Absorbed; G, A, M, IgG, IgA, IgM.

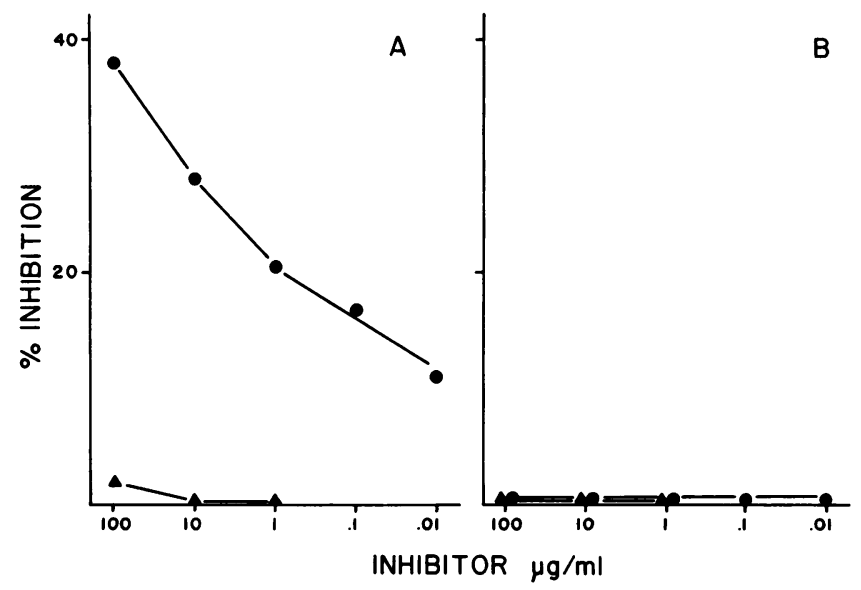

Figure 4. Ability of PRP (๑) or dextran B-1355 (A) to inhibit anti$\mathrm{Id}^{\mathrm{HH}} \rightarrow \mathrm{Id}^{\mathrm{HH}}(A)$ or anti-Id ${ }^{\mathrm{HH}} \rightarrow \mathrm{Id}^{\mathrm{PT}}(B)$. Id-coated wells were incubated with indicated concentrations of inhibitor or buffer for $2 \mathrm{~h}$ at $37^{\circ} \mathrm{C}$. An equal volume of anti-Id, containing inhibitor or buffer, was added for $2 \mathrm{~h}$ at $37^{\circ} \mathrm{C}$. Bound murine antibody was detected as described in Methods. All samples were tested in duplicate. Percent inhibition was calculated according to: $100 \times 1-(\mathrm{OD}$ in presence of inhibitor)/(OD in absence of inhibitor).
Table I. Inhibition of Anti-PRP or Anti-TT Paratopes by Anti-Id*

\begin{tabular}{clll}
\hline & & \multicolumn{2}{l}{ Inhibition with: } \\
\cline { 3 - 4 } Serum & Paratope & Anti-Id & Anti-Id $^{\text {PT }}$ \\
\hline & & $\%$ & $\%$ \\
H.H. Pre & Anti-PRP & 73 & 38 \\
Post & Anti-PRP & 51 & 0 \\
P.T. Pre & Anti-PRP & 0 & 0 \\
Post & Anti-PRP & 43 & 34 \\
H.H. Post & Anti-TT & 7 & 8 \\
P.T. Post & Anti-TT & 0 & 4 \\
& & &
\end{tabular}

*A dilution of serum equivalent to $0.2 \mu \mathrm{g}$ anti-PRP/ml or $50 \mathrm{U}$ anti$\mathrm{TT} / \mathrm{ml}$ was mixed with an equal volume of 1:10 anti-Id or 1:10 normal mouse serum (NMS) and incubated for $2 \mathrm{~h}$ at $37^{\circ} \mathrm{C}$. The mixtures were then tested for anti-PRP antibody activity using the ELISA as described in Methods. All samples were tested in duplicate. Percent inhibition was calculated according to: $100 \times 1-$ (anti-PRP antibody activity in presence of anti-Id)/(anti-PRP antibody activity in presence of NMS).

were also apparent when heterologous anti-Id was used as an inhibitor. Anti-Id ${ }^{\mathrm{HH}}$ inhibited $43 \%$ of the postvaccination PT anti-PRP activity but failed to inhibit PT prevaccination antibodies. In contrast, anti-Id ${ }^{\mathrm{PT}}$ did not inhibit $\mathrm{HH}$ postvaccination anti-PRP antibodies but did inhibit $38 \%$ of the prevaccination antibody activity. H.H. and P.T. anti-tetanus antibodies were only slightly inhibited by either anti-Id. To rule out the possibility that the inhibitory effect was due to murine anti-PRP antibodies contaminating the anti-Id antisera, anti$\mathrm{Id}^{\mathrm{HH}}$ and anti-Id ${ }^{\mathrm{PT}}$ were tested for the presence of murine antiPRP. No PRP-specific antibody activity was detected. The level of specific inhibition obtained with each anti-Id serum was dependent upon the anti-Id concentration. Thus, anti$\mathrm{Id}^{\mathrm{HH}}$ and anti-Id ${ }^{\mathrm{PT}}$ showed linear decreases in inhibitory activity as they were diluted from 1:20 to 1:320 (data not shown).

Crossreactive idiotypes (CRI) and anti-PRP titers of preand post-PRP vaccination sera. The pre- and post-PRP vaccination sera from H.H., P.T., and three additional unrelated subjects were tested quantitatively for CRI, using the inhibition ELISA, and for total anti-PRP antibody using the PRPreactive ELISA. As shown in Table II, immunization with PRP induced 4-59-fold increases in serum antibody concentration. All the sera, except for the prevaccination serum of subject D.T., tested positive for the CRIs defined by anti$\mathrm{Id}^{\mathrm{HH}} \rightarrow \mathrm{Id}^{\mathrm{PT}}$ and anti-Id ${ }^{\mathrm{PT}} \rightarrow \mathrm{Id}^{\mathrm{HH}}$. The change in CRI titers, however, did not always parallel the increases in anti-PRP antibody content. For example, the CRI detected by anti$\mathrm{Id}^{\mathrm{HH}} \rightarrow \mathrm{Id}^{\mathrm{PT}}$ in H.H. serum did not change concentration after vaccination despite a fourfold rise in anti-PRP titer. In contrast, this same CRI increased in P.T. serum 24-fold after vaccination, which was equivalent to the increase in the total anti-PRP antibody, i.e., 26-fold. The CRI defined by anti$\mathrm{Id}^{\mathrm{PT}} \rightarrow \mathrm{Id}^{\mathrm{HH}}$ similarly increased in P.T. serum in proportion to the rise in total antibody. The other sera had variable CRI titers, and although the CRI titer always increased after PRP vaccination, the fold change was less than the change in total anti-PRP antibody. Absorption of both pre- and post-PRP vaccination sera with PRP-Sepharose removed $>90 \%$ of the anti-PRP and CRI activities (data not shown). 
Table II. Antibody and CRI Titers before and after Immunization with PRP

\begin{tabular}{|c|c|c|c|c|c|c|}
\hline \multirow[b]{2}{*}{ Serum } & \multicolumn{2}{|c|}{ Anti-PRP* } & \multicolumn{2}{|l|}{ Anti-Id ${ }^{\mathrm{HH}} \rightarrow \mathrm{Id}^{\mathrm{PT}}$} & \multicolumn{2}{|l|}{ Anti-Id ${ }^{\mathrm{PT}} \rightarrow \mathrm{Id}^{\mathrm{HH}}$} \\
\hline & $\mu g / m l$ & Fold change & Inhibition titer ${ }^{\ddagger}$ & Fold change & Inhibition titer ${ }^{\sharp}$ & Fold change \\
\hline $\begin{array}{r}\text { H.H. Pre } \\
\text { Post }\end{array}$ & $\begin{array}{r}50 \\
204\end{array}$ & 4.0 & $\begin{array}{l}1: 1,200 \\
1: 1,200\end{array}$ & 1.0 & $\begin{array}{l}1: 1,400 \\
1: 2,000\end{array}$ & 1.4 \\
\hline $\begin{array}{l}\text { P.T. Pre } \\
\text { Post }\end{array}$ & $\begin{array}{l}1.6 \\
41\end{array}$ & 26 & $\begin{array}{l}1: 115 \\
1: 2,700\end{array}$ & 24 & $\begin{array}{l}1: 140 \\
1: 3,000\end{array}$ & 21 \\
\hline $\begin{array}{r}\text { D.T. Pre } \\
\text { Post }\end{array}$ & $\begin{array}{l}2.3 \\
53\end{array}$ & 23 & $\begin{array}{r}<1: 50 \\
1: 150\end{array}$ & $>3.0$ & $\begin{array}{r}<1: 50 \\
1: 600\end{array}$ & $>12$ \\
\hline $\begin{array}{r}\text { D.S. Pre } \\
\text { Post }\end{array}$ & $\begin{array}{l}0.8 \\
47\end{array}$ & 59 & $\begin{array}{l}1: 110 \\
1: 2,000\end{array}$ & 18 & $\begin{array}{l}1: 150 \\
1: 540\end{array}$ & 3.6 \\
\hline $\begin{array}{l}\text { E.T. Pre } \\
\text { Post }\end{array}$ & $\begin{array}{l}1.0 \\
29\end{array}$ & 29 & $\begin{array}{l}1: 100 \\
1: 170\end{array}$ & 1.7 & $\begin{array}{l}1: 150 \\
1: 600\end{array}$ & 4.0 \\
\hline
\end{tabular}

* Serum antibody concentration was determined using the PRP-reactive ELISA as described in Methods. ${ }^{\ddagger}$ Inhibition titer/serum dilution required for $30 \%$ inhibition of anti-Id $\rightarrow$ Id reaction. The idiotype assay was the inhibition ELISA described in Methods.

\section{Discussion}

The findings reported here document the existence of CRIs associated with the PRP-specific antibodies of five unrelated adults. This was shown by the ability of two anti-Id antisera, prepared against $F\left(a^{\prime}\right)_{2}$ anti-PRP from two individuals, H.H. and P.T., to reciprocally crossreact with H.H. and P.T. anti$\mathrm{PRP}$ antibodies and their $\mathrm{F}\left(\mathrm{ab}^{\prime}\right)_{2}$ fragments. In addition, serum anti-PRP antibodies from three other individuals also expressed the CRIs defined by the heterologous anti-Id $\rightarrow$ Id reactions. The anti-Id antisera were specific for anti-PRP-associated Ids since high concentrations of PRP-absorbed H.H. and P.T. Ig, myeloma proteins, anti-PLA antibodies, and PRP-absorbed pooled human Ig failed to inhibit either homologous or heterologous anti-Id $\rightarrow$ Id reactions. Specificity was further demonstrated by the ability of anti-Id to partially inhibit the binding of anti-PRP to PRP, but not the binding of anti-TT to TT.

Differences between the two anti-Id antisera were apparent in their reactivity patterns with homologous and heterologous Id. Thus, anti-Id ${ }^{\mathrm{HH}}$ bound less well to microtiter wells coated with $\mathrm{Id}^{\mathrm{PT}}$ than to wells coated with $\mathrm{Id}^{\mathrm{HH}}$, while anti-Id ${ }^{\mathrm{PT}}$ bound nearly equivalently to wells coated with either $\mathrm{Id}^{\mathrm{PT}}$ or $\mathrm{Id}^{\mathrm{HH}}$. These results suggest that anti-Id ${ }^{\mathrm{HH}}$ contains not only anti-Id antibodies that crossreact with $\mathrm{Id}^{\mathrm{PT}}$, but also a substantial number of anti-Id antibodies that are specific for Id determinants private to $H . H$. In contrast, anti-Id ${ }^{\text {PT }}$ appears to contain predominantly anti-Id specificities reactive with public or CRI determinants. Consistent with this interpretation are the findings that $\mathrm{Id}^{\mathrm{PT}}$ was 10 -fold more efficacious as an inhibitor of the anti-Id ${ }^{\mathrm{HH}} \rightarrow \mathrm{Id}^{\mathrm{PT}}$ reaction than of the anti-Id ${ }^{\mathrm{HH}} \rightarrow \mathrm{Id}^{\mathrm{HH}}$ reaction, whereas $\mathrm{Id}^{\mathrm{HH}}$ had equivalent inhibitory activity in both the anti-Id ${ }^{\mathrm{PT}} \rightarrow \mathrm{Id}^{\mathrm{PT}}$ and anti-Id ${ }^{\mathrm{PT}} \rightarrow \mathrm{Id}^{\mathrm{HH}}$ reactions.

The interpretation of Id crossreactivity depends critically upon the nature of the interaction between anti-Id and antiPRP antibodies. The anti-Ids could be functioning as conventional anti-CRI antibodies, i.e., they are recognizing conserved Id determinants shared between structurally similar $\mathrm{V}$ domains. Alternatively, the anti-Ids could be recognized by
anti-PRP antibodies because the anti-Ids themselves express Id determinants which behave, at least functionally, like socalled internal images of PRP. Ligand inhibition of anti-Id $\rightarrow$ Id reactions is a necessary condition for internal image-type anti-Ids. Since the recognition of CRI determinants, as defined by the interaction between anti-Id and heterologous anti-PRP antibodies (Id), was not inhibitable by PRP, it appears that the anti-CRI specificities were not functioning as PRP internal images. We therefore interpret the observed Id crossreactivity in terms of anti-Id recognition of Id determinants expressed by structurally related anti-PRP V domains. This view is supported by the IEF studies of Insel et al., which demonstrated restricted and frequently identical anti-PRP spectrotypes among unrelated individuals (7). Taken together, our data and those of Insel et al., suggest that the adult antibody response to PRP is composed of a limited number of conserved $V$ regions that may be germ-line encoded.

Unlike several well-studied murine CRIs which serve as markers for one or a few homologous germ-line $V_{H}$ genes (19-21) and whose expression is generally linked to particular IgH alleles, the expression of anti-PRP-associated CRI appears not to be genetically restricted, since CRI was present in five of five unrelated individuals. Since we have not tested Ig allotypes we cannot exclude the possibility that the subjects were identical at the relevant Ig loci, although this seems improbable. Rather, we suggest that the $V_{H}$ and/or $V_{L}$ genes responsible for CRI expression may be ubiquitous in the germ-line. A similar lack of genetic restriction has been observed with murine anti-poly- $\left(\mathrm{Glu}^{60}, \mathrm{~L}-\mathrm{Ala}^{30}, \mathrm{~L}-\mathrm{Tyr}^{60}\right)$ antibodies (22) and human antibodies to $N$-acetyl-D-glucosamine (23). Further studies with a larger panel of subjects are required in order to define the extent of anti-PRP-associated CRI penetrance and to determine whether CRI expression is influenced by genetic determinants such as the $K_{\mathrm{m}}$ and $G_{\mathrm{m}}$ allotypes, which have been implicated in regulating the antibody response to PRP $(24,25)$ and in affecting susceptibility to Hib infection (26).

The structural basis of CRI expression has yet to be determined. Particular $V_{H}$ or $V_{L}$ hypervariable region sequences may be involved, as has been shown for the CRIs expressed by 
murine anti- $\alpha(1-3)$ dextran antibodies (27) and human antiIgG antibodies (28), respectively. Alternatively, CRI could be determined by framework regions, or $V_{H} / V_{L}$ combinatorial determinants. Anti-PRP antibodies have primarily kappa light chains (Lucas, A., unpublished observations) (29), and this may indicate a requirement for particular $V_{K}$ regions in CRI expression. While some private Id determinants may be in or near the combining site as shown by PRP inhibition of the homologous reaction between anti-Id ${ }^{\mathrm{HH}}$ and $\mathrm{Id}^{\mathrm{HH}}$, the public or CRI determinants are probably distant from the PRP combining site since the heterologous reactions were not inhibitable with PRP. These results are similar to those of Greenspan and Davie (30) and Reth et al. (31), which showed that the CRIs expressed by anti-streptococcal group A carbohydrate antibodies and by anti-4(hydroxy-3-nitrophenyl)acetyl antibodies were not hapten inhibitable, whereas the less crossreactive or private Ids were susceptible to hapten inhibition.

The CRIs defined by the heterologous anti-Id $\rightarrow$ Id reactions were expressed by both naturally occurring and immunization-induced antibodies, implying that the clonal origins of these two populations may overlap to some degree. This finding is consistent with previous studies showing that IEF spectrotype patterns of "natural" and immunization-induced anti-PRP antibodies were often similar, although occasionally new clonotypes appeared after immunization (7). Our results show that while CRI serum titer increased after PRP immunization (with the exception of H.H., see below), it did not always parallel the increase in the total anti-PRP antibody titer, suggesting that the fraction of the total antibody that was CRI positive diminished after immunization. This apparent diminution may be due to the emergence of CRI-negative antibodies, i.e., new clonotypes, or to the extinction of CRI determinants by somatic mutation or active suppression. Note that individual HH did not show an increase in serum CRI titer (as defined by anti-Id ${ }^{\mathrm{HH}} \rightarrow \mathrm{Id}^{\mathrm{PT}}$ ) after PRP immunization despite a fourfold increase in total anti-PRP antibody. Although the anti-Id ${ }^{\mathrm{HH}}$ antiserum was prepared against H.H. anti-PRP antibodies isolated from the postimmunization serum, the antiCRI reactivity of this antiserum was with Ids that predominated the preimmunization antibody population, but which were also present in the postimmunization population.

The experiments examining the inhibition of anti-PRP paratopes with anti-Id are informative for several reasons. First, the results confirm the specificity of the anti-Id reagents, since anti-PRP but not anti-TT paratopes were inhibited. Second, they are consistent with the finding of the ELISA inhibition assays, showing that quantitative changes in serum Id composition occur as a result of PRP immunization. For example, the fraction of anti-PRP paratopes inhibitable by anti$\mathrm{Id}^{\mathrm{PT}}$ diminished in H.H. serum after PRP immunization, again suggesting that CRI predominated the preimmunization H.H. antibody population. Third, the inhibition of heterologous anti-PRP paratopes by anti-Id is a further demonstration of the Id crossreactivity between H.H. and P.T. anti-PRP antibodies. Fourth, the degree of inhibition of anti-PRP paratopes inhibitable by heterologous anti-Id provides a minimal estimate of the fraction of the total anti-PRP antibody population expressing CRI, which for P.T. postimmunization antibodies was $\sim 43 \%$ and for H.H. preimmunization antibodies was $\sim 38 \%$. These high values indicate that CRI-positive antibodies can comprise a major proportion of the total antibody population and lend further support to the notion that a restricted number of $\mathrm{V}$ regions predominates the PRP-specific antibodies of these individuals.

The polyclonal anti-Id antisera used in this study were made in mice so that in the future monoclonal anti-Id antibodies can be isolated. Such reagents are necessary for definition of the idiotopes comprising the CRI families recognized by anti$\mathrm{Id}^{\mathrm{HH}}$ and anti-Id ${ }^{\mathrm{PT}}$. Monoclonal anti-Ids would also be useful for investigating the feasibility of an anti-Id Hib vaccine. Both polyclonal and monoclonal anti-Id antibodies have been used successfully in animal models to induce protective immunity to parasites (9), viruses $(10-12)$, and bacteria $(13,14)$. The study by Stein et al. demonstrated that administration of monoclonal anti-Id to neonatal mice primed for protective anti-Escherichia coli carbohydrate immunity (14). In addition, anti-Id antibodies can prime neonatal mice for expression of a levan-specific Id even though this Id is normally not expressed during the response to levan (32). It remains to be determined whether infants express, either at the serum or cellular level, the CRIs defined by anti-Id ${ }^{\mathrm{HH}}$ or anti-Id ${ }^{\mathrm{PT}}$, although it is known that immunization of infants with PRP protein conjugates induces PRP-specific antibodies that are spectrotypically similar to that of the adult (8). Therefore, despite the normal ontogenic delay in the expression of serum antibodies, PRP-specific B cells are present in the infant and they can be induced to secrete antibodies upon appropriate stimulation. This fact, taken with our present findings of recurrent CRI expression by adult anti-PRP antibodies, raises the possibility that some anti-CRI specificities could function as a protective vaccine in the Hib system.

\section{Acknowledgments}

The author thanks John Bastian, Linda Thompson, and Park Trefts for discussion, Hans Spiegelberg for critical review of the manuscript, Porter Anderson for his provision of PRP, and Margaret Stone for expert preparation of the manuscript. The generous serum donations of H.H., P.T., D.S., D.T., and E.T. are gratefully acknowledged.

A. Lucas is the recipient of a National Institutes of Health New Investigator Award.

\section{References}

1. Sell, S. H., and P. E. Wright, editors. 1982. Haemophilus influenzae. Epidemiology, Immunology, and Prevention of Disease. Elsevier Science Publishing Co., New York.

2. Fothergill, L. D., and J. Wright. 1933. Influenzae meningitis: the relation of age incidence to the bactericidal power of blood against the causal organism. J. Immunol. 24:273-284.

3. Anderson, P., G. Peter, R. B. Johnston, Jr., L. H. Wetterlow, and D. H. Smith. 1972. Immunization of humans with polyribophosphate, the capsular antigen Hemophilus influenzae, type b. J. Clin. Invest. 51:39-44,

4. Smith, D. H., G. Peter, D. L. Ingram, A. L. Harding, and P. Anderson. 1973. Responses of children immunized with the capsular polysaccharide of Hemophilus influenzae, type b. Pediatrics. 52:637644.

5. Robbins, J. B., J. C. Parke, Jr., R. Schneerson, and J. K. Whisnant. 1973. Quantitative measurement of "natural" and immunization-induced Haemophilus influenzae type b capsular polysaccharide antibodies. Pediatr. Res. 7:103-110.

6. Käyhty, H., V. Karanko, H. Peltola, and P. H. Mäkelä. 1984. Serum antibodies after vaccination with Haemophilus influenzae type b capsular polysaccharide and responses to reimmunization: no evidence of immunologic tolerance or memory. Pediatrics. 74:857-865. 
7. Insel, R. A., A. Kittelberger, and P. Anderson. 1985. Isoelectric focusing of human antibody to the Haemophilus influenzae b capsular polysaccharide: restricted and identical spectrotypes in adults. J. Immunol. 135:2810-2816.

8. Insel, R. A., and P. W. Anderson. 1986. Oligosaccharide-protein conjugate vaccines induce and prime for oligoclonal $\mathrm{IgG}$ antibody responses to the Haemophilus influenzae b capsular polysaccharide in human infants. J. Exp. Med. 163:262-269.

9. Sacks, D. L., K. M. Esser, and A. Sher. 1982. Immunization of mice against African trypanosomiasis using anti-idiotypic antibodies. J. Exp. Med. 155:1108-1119.

10. Kennedy, R. C., R. L. Melnick, and G. R. Dreesman. 1984. Antibody to hepatitis $\mathrm{B}$ virus induced by injecting antibodies to the idiotype. Science (Wash. DC). 223:930-931.

11. Sharpe, A. H., G. N. Gaulton, K. K. McDade, B. N. Fields, and M. I. Greene. 1984. Syngeneic monoclonal antiidiotype can induce cellular immunity to virus. J. Exp. Med. 160:1195-1205.

12. Uytdehaag, F. G. C. M., and A. D. M. E. Osterhaus. 1985. Induction of neutralizing antibody in mice against poliovirus type II with monoclonal anti-idiotypic antibody. J. Immunol. 134:12251229 .

13. McNamara, M. K., R. E. Ward, and H. Kohler. 1984. Monoclonal idiotope vaccine against Streptococcus pneumoniae infection. Science (Wash. DC). 226:1325-1326.

14. Stein, K. E., and T. Söderström. 1984. Neonatal administration of idiotype or antiidiotype primes for protection against Escherichia coli K13 infection in mice. J. Exp. Med. 160:1001-1011.

15. Ashwell, G. 1957. Colorimetric analysis of sugars. Methods Enzymol. 3:73-105.

16. Nisonoff, A., F. C. Wissler, L. N. Lipman, and D. L. Woerndey. 1960. Separation of univalent fragments from the bivalent rabbit antibody molecule by reduction of disulfide bonds. Arch. Biochem. Biophys. 89:230-244.

17. Anthony, B. F., N. F. Concepcion, S. A. McGeary, J. I. Wart, D. C. Heiner, P. Shapshak, and R. A. Insel. 1982. Immunospecificity and quantitation of an enzyme-linked immunosorbent assay for group B streptococcal antibody. J. Clin. Microbiol. 16:350-354.

18. Rubin, R. L., F.-L. Tang, A. H. Lucas, H. L. Spiegelberg, and E. M. Tan. 1986. IgG subclasses of anti-tetanus toxoid antibodies in adult and newborn normal subjects and in patients with systemic lupus erythematosus, Sjogren's syndrome, and drug-induced autoimmunity. J. Immunol. 137:2522-2527.

19. Crews, S., J. Griffin, H. Huang, K. Calame, and L. Hood. 1981. A single $V_{H}$ gene segment encodes the immune response to phosphorylcholine: somatic mutation is correlated with the class of the antibody. Cell. 25:59-66.

20. Siekevitz, M., S.-Y. Huang, and M. L. Gefter. 1983. The genetic basis of antibody production: a single heavy chain variable region gene encodes all molecules bearing the dominant anti-arsonate idiotype in the strain A mouse. Eur. J. Immunol. 13:123-132.
21. Boersch-Supan, M. E., S. Agarwal, M. E. White-Scharf, and T. Imanishi-Kari. 1985. Heavy chain variable region. Multiple gene segments encode anti-4-(hydroxy-3-nitro-phenyl)acetyl idiotypic antibodies. J. Exp. Med. 161:1272-1292.

22. Ju, S. T., M. Pierres, R. N. Germain, B. Benacerraf, and M. E. Dorf. 1979. Idiotypic analysis of anti-GAT antibodies. VI. Identification and strain distribution of the GA-1 idiotype. J. Immunol. 123:2505-2510.

23. Emmrich, F., B. Greger, and K. Eichmann. 1983. A crossreacting human idiotype (B17) associated with antibodies to $\mathrm{N}$-acetylD-glucosamine. Specificity, immunoglobulin class association, and distribution in the population. Eur. J. Immunol. 13:273-278.

24. Ambrosino, D. M., V. A. Barrus, G. D. DeLange, and G. R. Siber. 1986. Correlation of the $\mathrm{Km}(1)$ immunoglobulin allotype with anti-polysaccharide antibodies in Caucasian adults. J. Clin. Invest. 78:361-365.

25. Pandey, J. P., G. Virella, C. B. Loadholt, H. H. Fudenberg, C. U. Kyong, and R. M. Galbraith. 1979. Association between immunoglobulin allotypes and immune responses to Hemophilus influenzae and meningococcus polysaccharides. Lancet. i:190-192.

26. Granoff, D. M., E. Boies, J. Squires, J. P. Pandey, B. Suarez, J. Oldfather, and G. E. Rodey. 1984. Interactive effect of genes associated with immunoglobulin allotypes and HLA specificities on susceptibility to Haemophilus influenzae disease. J. Immunogenet. (Oxf.). 11:181188.

27. Clevinger, B., J. Schilling, L. Hood, and J. M. Davie. 1980. Structural correlates of cross-reactive and individual idiotypic determinants on murine antibodies to $\alpha(1 \rightarrow 3$ dextran $)$. J. Exp. Med. 151:1059-1070.

28. Chen, P. P., S. Fong, D. Normansell, R. A. Houghton, J. G. Karras, J. H. Vaughan, and D. A. Carson. 1984. Delineation of a cross-reactive idiotype on human autoantibodies with antibody against a synthetic peptide. J. Exp. Med. 159:1502-1511.

29. Insel, R. A., P. Anderson, M. E. Pichichero, M. A. Amstey, G. Ekborg, and D. H. Smith. 1982. Anticapsular antibody to Hemophilus influenzae type b. In Hemophilus Influenzae, Epidemiology, Immunology, and Prevention of Disease. S. H. Sell and P. E. Wright, editors. Elsevier Science Publishing Co., New York. 155-168.

30. Greenspan, N. S., and J. M. Davie. 1985. Serologic and topographic characterization of idiotopes on murine monoclonal antistreptococcal group A carbohydrate antibodies. J. Immunol. 134:1065-1072.

31. Reth, M., T. Imanishi-Kari, and K. Rajewsky. 1979. Analysis of the repertoire of anti-(4-hydroxy-3-nitro-phenyl) acetyl (NP) antibodies in C57BL/6 mice by cell fusion. II. Characterization of idiotopes by monoclonal anti-idiotope antibodies. Eur. J. Immunol. 9:1004-1013.

32. Hiernaux, J., C. Bona, and P. J. Baker. 1981. Neonatal treatment with low doses of anti-idiotypic antibody leads to the expression of a silent clone. J. Exp. Med. 153:1004-1006. 